Copyright (C) 2020 University of Bucharest Printed in Romania. All rights reserved

ISSN print: $1224-5984$

ISSN online: $2248-3942$
Rom Biotechnol Lett. 2020; 25(1): 1246-1252

doi: $10.25083 / \mathrm{rbl} / 25.1 / 1246.1252$

Received for publication, October, 5, 2018

Accepted, November, 23, 2018

Original paper

\title{
Exploration of Synergistic Antibiotic Interactions in Klebsiella pneumoniae
}

\author{
OZGE UNLU ${ }^{1}$, KAAN YILANCIOGLU ${ }^{2 *}$
}

${ }^{1}$ Beykent University, Faculty of Medicine, Department of Medical Microbiology, Beykent, Buyukcekmece, Istanbul, Turkey

${ }^{2}$ Uskudar University, Faculty of Engineering and Natural Sciences, Department of Bioengineering, Uskudar, Istanbul, Turkey

\begin{abstract}
Klebsiella pneumoniae is an opportunistic pathogen resulting broad range of infections. Antimicrobial resistance causes a serious problem, which require immediate action. Treatment options are running out and the success rate of treatment is decreasing because of the strong multi-drug resistance. Synergistic antimicrobial combination therapy is a rational option with potential benefits. However, some antibiotic combinations might show antagonistic interaction patterns that hinder treatment efforts. Thus, screening drug interactions is crucial. In this study, we screened response of susceptible and multi-drug resistant $K$. pneumoniae strains to several antibiotic combinations. We used Amikacin, Ciprofloxacin, Kanamycin, Piperacillin, Ampicillin and Chloramphenicol in pairwise combinations. According to the results Kanamycin - Ciprofloxacin, Ampicillin - Piperacillin and Chloramphenicol - Piperacillin pairwise combinations were found as synergistic. Chloramphenicol - Amikacin and Chloramphenicol - Kanamycin combinations were found as antagonistic and Amikacin - Piperacillin and Kanamycin - Piperacillin combination were found as additive for both strains. Drug interaction is a complex mechanism. Different strains may respond differently to same combination treatments. Thus, each strain should be tested for drug interactions before combination therapy is given. In addition, antagonistic drug interactions should be considered.
\end{abstract}

Keywords Antibiotic, Antagonism, Synergism, Drug Interaction.

To cite this article: UNLU O, YILANCIOGLU K. Exploration of Synergistic Antibiotic Interactions in Klebsiella pneumoniae. Rom Biotechnol Lett. 2020; 25(1): 1246-1252. DOI: $10.25083 / \mathrm{rbl} / 25.1 / 1246.1252$

*Corresponding author: KAAN YILANCIOGLU, Uskudar University, Faculty of Engineering and Natural Sciences, Department of Bioengineering, Uskudar, Istanbul, Turkey

E-mail: kaanyl@gmail.com 


\section{Introduction}

Klebsiella pneumoniae strains are opportunistic pathogens which result broad range of infections, varying from benign urinary tract infections to pneumonia and more severe bacteremia. Patients gastrointestinal tracts are primary reservoirs. Hospital personnel can also play an important role in transmission of the pathogen (DIANCOURT $\&$ al [1], PENA \& al [2]). Moreover, use of invasive medical devices and urinary catheters increase the rate of nosocomial infections while emerging antimicrobial resistance complicates the therapy. Antimicrobial resistance is usually carried on mobile elements such as plasmids and transposons. These elements enable resistance transmission to other strains and species and it results development of multi drug resistant strains which is the major concern of public health (FALAGAS \& al [3], KUMARASAMY \& al [4], PATERSON \& al [5], SHANTI \& al [6]). According to National Nosocomial Infections Surveillance System 2003 report, $47 \%$ increase in resistance to third generation of cephalosporins is detected among $K$. pneumoniae which is isolated from intensive care units [7]. In addition to extended spectrum beta lactamase (ESBL) producing strains, carbapenem resistant strains were reported from different countries recently (KUMARASAMY \& al [4], NORDMANN \& al [8]).

As the investments for the discovery of new antibiotics remain insufficient in the scope of drug development programs, clinicians started to seek for new therapeutic strategies for the infections. Antimicrobial combination therapies are one of those approaches to reduce emerging resistance. In addition, it increases antimicrobial activity with potential synergistic effect when two or more agents are combined in therapy (ADBUL RAHIM \& al [9], CHANDRASEKARAN [10], RAHAL [11]). On the other hand, one drug may have an antagonistic interaction with the other drug. Thus, to avoid this risk, drug interactions should be considered before the combination therapy is given to the patient. In this study, we aimed to screen antimicrobial resistance genes and examine the response to six pairwise antibiotic combinations against one susceptible and one resistant $K$. pneumoniae strains isolated from urinary tract infections.

\section{Materials and Methods}

\section{Bacterial strains}

K. pneumoniae strains isolated from patients with UTIs obtained from Istanbul University, Faculty of Medicine. Antibiograms were performed with disc diffusion method. Glycerol stocks of bacterial strains were prepared and stored at $-20^{\circ} \mathrm{C}$.

\section{DNA extraction}

A single colony from each strain was suspended in 50 $\mu l$ ultra-pure water. The suspension was heated at $95^{\circ} \mathrm{C}$ for 10 minutes and centrifuged at $14.000 \mathrm{rpm}$ for 10 minutes, $30 \mu 1$ of supernatant was used as DNA template for PCR.

\section{Detection of antimicrobial resistance genes}

Strains were analyzed for the presence of TEM-1, SHV-1, CTX-M-1 extended spectrum beta lactamase, qnrA1, qnrB1, qnrS1 plasmid mediated quinolone, sulI and sulII sulfonamide, strA, strB aminoglycoside and cat1, cat2 chloramphenicol resistance genes. Table 1 outlines the sequences, predicted amplicon sizes and references of the primers of interest.

Table 1. Primers related to antimicrobial resistance genes used in this study

\begin{tabular}{|l|l|c|c|}
\hline \multicolumn{1}{|c|}{ Genes } & \multicolumn{1}{|c|}{ Primers Sequences (5'-3') } & $\begin{array}{c}\text { Amplicons } \\
\text { (bp) }\end{array}$ & References \\
\hline blaSHV-1 & $\begin{array}{l}\text { GGC CGC GTA GGC ATG ATA GA } \\
\text { CCC GGC GAT TTG CTG ATT TC }\end{array}$ & 714 & {$[18]$} \\
\hline bla TEM-1 & $\begin{array}{l}\text { CAG CGG TAA GAT CCT TGA GA } \\
\text { ACT CCC CGT CGT GTA GAT AA }\end{array}$ & 643 & {$[18]$} \\
\hline $\boldsymbol{b l a C T X - M - 1}$ & $\begin{array}{l}\text { AAC CGT CAC GCT GTT GTT AG } \\
\text { TTG AGG CTG GGT GAA GTA AG }\end{array}$ & 766 & {$[18]$} \\
\hline qnrA & $\begin{array}{l}\text { AGAGGATTTCTCACGCCAGG } \\
\text { TGCCAGGCACAGATCTTGAC }\end{array}$ & 580 & {$[19]$} \\
\hline qnrB & $\begin{array}{l}\text { GGMATHGAAATTCGCCACTG } \\
\text { TTTGCYGYYCGCCAGTCGAA* }\end{array}$ & 264 & {$[19]$} \\
\hline qnrS & $\begin{array}{l}\text { GCAAGTTCATTGAACAGGGT } \\
\text { TCTAAACCGTCGAGTTCGGCG }\end{array}$ & {$[19]$} \\
\hline sulI & $\begin{array}{l}\text { ATG GTG ACG GTG TTC GGC ATT CTG } \\
\text { GCT AGG CAT GAT CTA ACC CTC GG }\end{array}$ & 841 & {$[20]$} \\
\hline sulII & $\begin{array}{l}\text { AGG GGG CAG ATG TGA TCG AC } \\
\text { GCA GAT GAT TTC GCC AAT TG }\end{array}$ & 249 & {$[21]$} \\
\hline strA & $\begin{array}{l}\text { CTT GGT GAT AAC GGC AAT TC } \\
\text { CCA ATC GCA GAT AGA AGG C }\end{array}$ & 548 & {$[21]$} \\
\hline strB & $\begin{array}{l}\text { ATC GTC AAG GGA TTG AAA CC } \\
\text { GGA TCG TAG AAC ATA TTG GC }\end{array}$ & 509 & {$[18]$} \\
\hline cat1 & $\begin{array}{l}\text { CTT GTC GCC TTG CGT ATA AT } \\
\text { ATC CCA ATG GCA TCG TAA AG }\end{array}$ & 508 & 547 \\
\hline cat2 & $\begin{array}{l}\text { AAC GGC ATG ATG AAC CTG AA } \\
\text { ATC CCA ATG GCA TCG TAA AG }\end{array}$ & {$[18]$} \\
\hline
\end{tabular}


All amplifications were conducted using $10 \mathrm{pmol}$ of each primer (Biomatik, USA), $12.5 \mu$ l HS-Taq PCR Master Mix and $3 \mu \mathrm{l}$ DNA template in a total $25 \mu \mathrm{l}$ reaction mixture. Amplicons were separated in $2 \%$ agarose gel (Prona, Spain) by unidirectional electrophoresis using $1 \mathrm{X}$ TBE buffer (Gibco, Thermo Fisher Scientific, USA) and visualized by staining with ethidium bromide. Fragment size was determined by comparison with $100 \mathrm{bp}$ or $1 \mathrm{~kb}$ gene rulers (Thermo Scientific, USA) according to the size of amplicon.

\section{Drug interaction experiments}

Strains were plated on LB agar for colony formation prior to preparation of the starter cultures. Colonies were picked and grown in LB overnight for MIC and interaction experiments.

Drug-interaction experiments were done by using a $4 \times 4$ checkerboard assay. According to the concentration of each drug used in the assay increases gradually in each axis with a starting drug concentration zero (no drug). Clinically isolated $K$. pneumoniae strains were grown in LB media and treated with the pairwise combination of six different antibiotics namely Amikacin (AMK), Ciprofloxacin (CIP), Kanamycin (KAN), Piperacillin (PIP), Ampicillin (AMP) and Chloramphenicol (CHL), and with different combinatorial concentrations. End-point optical density (OD-600 nm) measurements were done at the end of over-night incubation by using 96-well microplate reader. In the drug interaction experiments, each individual drug, was used at the concentration of that was > 50\% inhibition at the highest dose and $<50 \%$ inhibition at the lowest dose as described detailed in a previous study (CHANDRASEKARAN \& al [10]). All drugs were purchased from Sigma. MICs for each drug were found by using simple two-fold dilution assay. Interactions were quantified based on the Bliss independence model utilizing probabilistic theory to model the effects of individual drugs in a combination as independent yet competing events by using MATLAB (YADAV \& al [12]).

\section{Results}

Results of disc diffusion assays revealed that one strain is multi-drug resistant and the second strain is susceptible against all of the antibiotics tested except from ampicillin and ampicillin- sulbactam combination. Table 2 demonstrates susceptibility of the strains to investigated antimicrobials.

Table 2. Antibiogram results of clinical K.pneumoniae isolates

\begin{tabular}{|c|c|c|}
\hline Antibiotics & K. pneumoniae $(\mathbf{R})$ & K. pneumoniae $(\mathbf{S})$ \\
\hline Ampicillin & $\mathbf{R}$ & $\mathbf{R}$ \\
\hline Cefazolin & $\mathbf{R}$ & $S$ \\
\hline Gentamicin & $\mathrm{S}$ & $\mathrm{S}$ \\
\hline Tobramycin & $\mathbf{R}$ & $S$ \\
\hline Ampicillin / Sulbactam & $\mathbf{R}$ & $\mathbf{R}$ \\
\hline Cefuroxime - Axetil & $\mathbf{R}$ & $\mathrm{S}$ \\
\hline Sefuroxime - Sodium & $\mathbf{R}$ & $\mathrm{S}$ \\
\hline Cotrimoxazole & $\mathrm{S}$ & $\mathrm{S}$ \\
\hline Amoxicillin / Clavulanic acid & $\mathbf{R}$ & $\mathrm{S}$ \\
\hline Imipenem & $\mathrm{S}$ & $\mathrm{S}$ \\
\hline Meropenem & $\mathrm{S}$ & $\mathrm{S}$ \\
\hline Ertapenem & $\mathrm{S}$ & $\mathrm{S}$ \\
\hline Amikacin & $\mathrm{S}$ & $S$ \\
\hline Cefoxitin & $\mathbf{R}$ & $S$ \\
\hline Cefotaxime & $\mathbf{R}$ & $S$ \\
\hline Ceftazidime & $\mathbf{R}$ & $S$ \\
\hline Cefepime & S & $S$ \\
\hline Ciprofloxacin & $\mathbf{R}$ & $S$ \\
\hline Norfloxacin & $\mathbf{R}$ & $S$ \\
\hline Nitrofurantoin & $\mathbf{R}$ & $S$ \\
\hline Piperacillin / Tazobactam & $\mathbf{R}$ & $S$ \\
\hline
\end{tabular}

\section{R- Resistant, S-Susceptible}

In order to understand molecular basis of resistance, we screened common resistance genes among pathogenic bacteria. Results show that resistant strain which is tolerant to third generation cephalosporins is blaTEM-1, blaSHV-1 and blaCTX-M-1 positive. In addition to beta lactamases, qnrB plasmid mediated quinolone resistance, strA, strB aminoglycoside and sulI, sulII sulfonamide resistance genes were found on the resistant strain which is resistant to ciprofloxacin, norfloxacin and tobramycin according to disc diffusion assays. blaSHV-1 and blaCTX-M-1 genes were also detected on the other strain which is only resistant to ampicillin and ampicillin-sulbactam combination.

PCR results revealed that relatively susceptible strain carried qnrB plasmid mediated quinolone resistance and sulI mediated sulfonamide resistance genes. Although the strain is susceptible to both quinolones and cotrimoxazole that might be resulted from suppression or expression impairment. Cat 1 and cat 2 chloramphenicol resistance genes 
were not detected in any of the strain. Both strains carried at least one of the resistance genes of interest indicating phenotype-genotype association in antibiotic resistance.

In order to evaluate antibiotic combinations on two clinical K. pneumoniae strains, we used Amikacin (AMK), Ciprofloxacin (CIP), Kanamycin (KAN), Piperacillin (PIP), Ampicillin (AMP) and Chloramphenicol (CHL) in pairwise combinations.

According to interaction experiments performed on susceptible strain, KAN-AMP, KAN-CIP, AMP-PIP,
CHL-PIP and AMK-CIP pairwise interactions were found synergistic. KAN-AMK, AMK-PIP, AMK-AMP, AMPCIP and KAN-PIP showed additive interaction. Moreover, CHL-AMK, CHL-AMP, CHL-CIP and CHL-KAN effected in antagonistic manner. PIP-CIP pairwise interaction was found as synergistic in low doses, however antagonistic interaction was observed in higher doses. Figure 1 demonstrates pairwise interactions of tested antibiotics on susceptible strain.
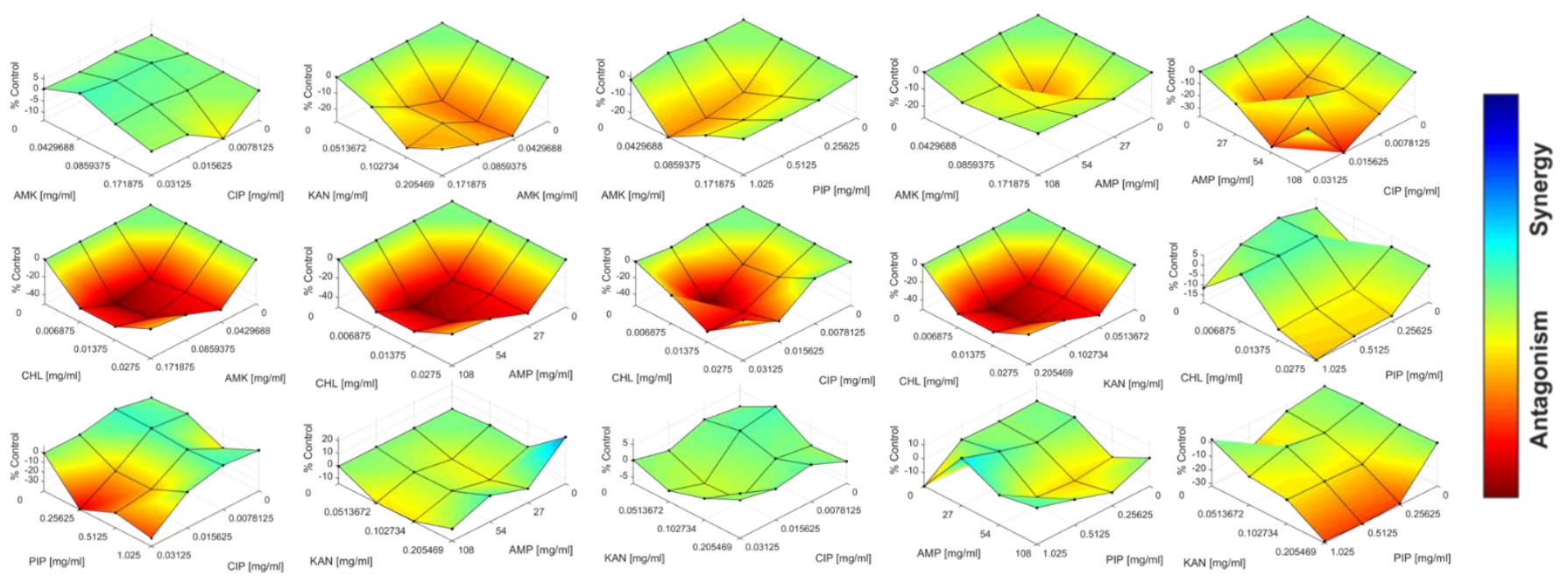

Figure 1. Bliss independence model of drug-drug interaction of susceptible strain of K. pneumoniae. Darker areas of the surface are demonstrating more antagonistic interactions compared to lighter areas representing more additive/synergistic interactions.

AMP-PIP, KAN-CIP, CHL-CIP, AMP-CIP and CHL-PIP pairwise interactions were found as synergistic according to the experiments conducted on resistant strain. Also AMK-CIP, AMK-PIP, CHL-AMP and KAN-PIP showed additive interaction while CHL-AMK, CHL-KAN, KAN-AMP, AMK-AMP and KAN-AMK were found as antagonistic. Figure 2 demonstrates pairwise interactions of tested antibiotics on resistant strain.

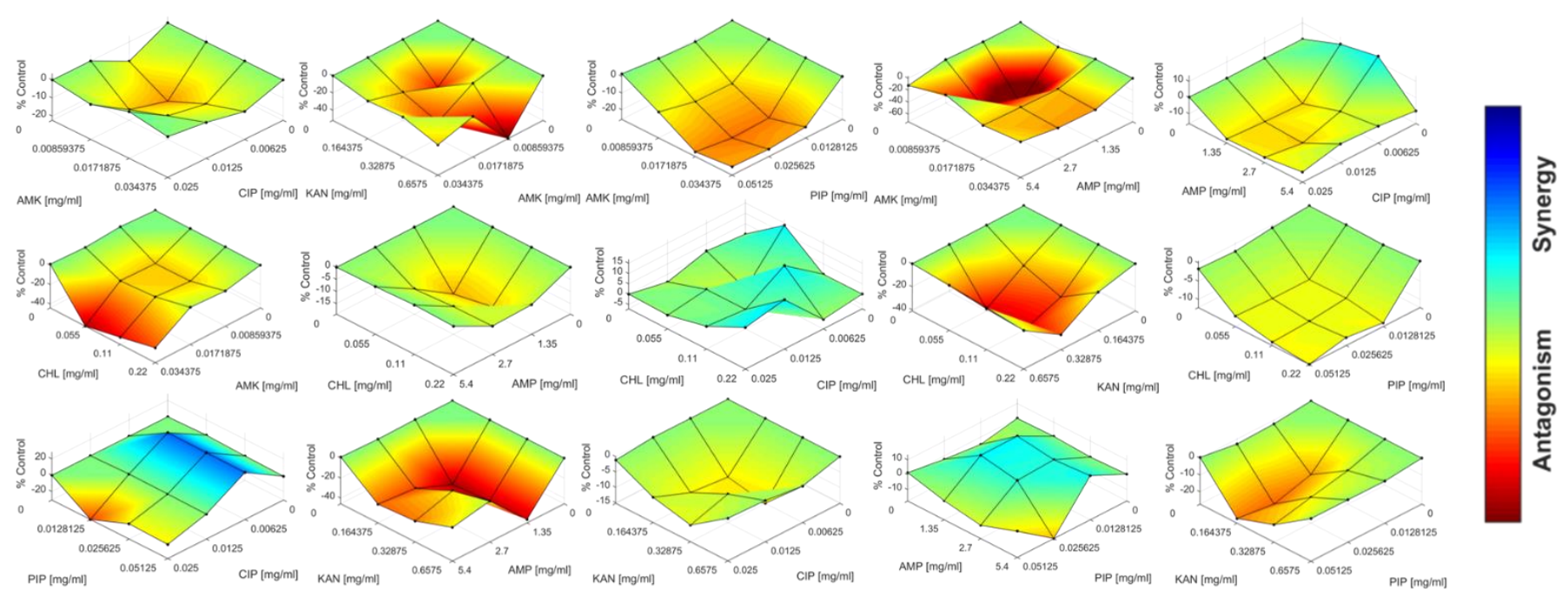

Figure 2. Bliss independence model of drug-drug interaction of MDR strain of K. pneumoniae. Darker areas of the surface are demonstrating more antagonistic interactions compared to lighter areas representing more additive/synergistic interactions. 


\section{Discussion}

Emerging drug resistance and lack of new antibiotics are one of the major concerns of public health prompting clinicians to find new alternatives for therapy. Antibiotic combination therapy is one of those alternatives to interfere with resistance, decrease the treatment time and get benefit of potential synergistic effects of drugs. However, in some cases drugs may have antagonistic interaction and suppress each other's effect. Thus, despite having many advantages clinicians should apply combination therapy responsibly and they should monitor interactions of the drugs before starting the therapy.

In this study we used one susceptible and one multidrug resistant clinically isolated $K$. pneumoniae strains. Strains investigated whether having genes that are responsible from beta lactam, aminoglycoside, chloramphenicol, sulfonamide and plasmid mediated quinolone resistance. PCR results revealed that susceptible strain which is only resistant to ampicillin and ampicillin-sulbactam combination carried blaSHV-1, blaCTX-M-1 extended spectrum beta lactamase genes, also sulI sulfonamide and qnrB plasmid mediated quinolone resistance genes. Moreover blaTEM-1, blaSHV-1 and blaCTX-M-1 extended spectrum beta lactamase genes, strA and strB aminoglycoside, sulI and sulII sulfonamide and qnrB plasmid mediated quinolone resistance genes were found on MDR $K$. pneumoniae strain, which is resistant to third generation cephalosporins, most of the aminoglycosides and quinolones. In other words, PCR results revealed that strains carried at least one of the resistance genes of interest suggesting phenotypegenotype relationship in resistance.

According to drug interaction experiments KAN-CIP, AMP-PIP and CHL-PIP pairwise combinations found as synergistic. Kanamycin targets ribosomes $30 \mathrm{~S}$ subunit while ciprofloxacin inhibits topoisomerase II and IV. Chloramphenicol and piperacillin targets ribosomes 50S subunit and penicillin binding proteins respectively. Synergistic interaction is usually encountered among the drugs that have different targets but in our study ampicillin and piperacillin both bind to penicillin binding protein and inhibit bacterial cell wall production showed synergistic interaction. Moreover, AMK-CIP pairwise combination found as synergistic on susceptible strain while additive interaction was observed with resistant strain. KAN-AMP combination which showed synergistic interaction on susceptible strain found as antagonistic on resistant strain. This may be a result of strA and strB aminoglycoside and blaTEM-1 beta lactam resistance genes that are found in resistant strain. Combination therapy may induce resistance pathways and it may reduce the effects of antibiotics when antibiotics used in pairwise combination.

Table 3. Drug interactions models and MIC ranges of antibiotics for both susceptible and resistant Klebsiella strains

\begin{tabular}{|c|c|c|c|c|c|c|}
\hline Antibiotics & $\begin{array}{c}\text { AMK } \\
\text { (MIC range } \\
0,008-0,034 \\
\text { mg/ml) }\end{array}$ & $\begin{array}{c}\text { CIP } \\
\text { (MIC range } \\
0,006-0,025 \\
\mathrm{mg} / \mathrm{ml}) \\
\end{array}$ & $\begin{array}{c}\text { KAN } \\
\text { (MIC range } \\
\mathbf{0 , 1 6 4}-\mathbf{0 , 6 5 7} \\
\mathrm{mg} / \mathrm{ml})\end{array}$ & $\begin{array}{c}\text { PIP } \\
\text { (MIC range } \\
0,012-0,051 \\
\text { mg/ml) }\end{array}$ & $\begin{array}{c}\text { AMP } \\
\text { (MIC range } \\
1,35-5,4 \\
\text { mg/ml) }\end{array}$ & $\begin{array}{c}\text { CHL (MIC } \\
\text { range } 0,055 \text { - } \\
0,22 \mathrm{mg} / \mathrm{ml})\end{array}$ \\
\hline $\begin{array}{c}\text { AMK } \\
\text { (MIC range } \\
0,008-0,034 \\
\text { mg/ml) }\end{array}$ & Additive & $\begin{array}{l}\text { Synergistic in } \\
\text { susceptible } \\
\text { strain } \\
\text { Additive in } \\
\text { resistant strain }\end{array}$ & $\begin{array}{l}\text { Additive in } \\
\text { susceptible } \\
\text { strain } \\
\text { Antagonistic in } \\
\text { resistant strain }\end{array}$ & Additive & $\begin{array}{l}\text { Additive in } \\
\text { susceptible } \\
\text { strain } \\
\text { Antagonistic in } \\
\text { resistant strain }\end{array}$ & Antagonistic \\
\hline $\begin{array}{c}\text { CIP } \\
\text { (MIC range } \\
0,006-0,025 \\
\text { mg/ml) }\end{array}$ & $\begin{array}{l}\text { Synergistic in } \\
\text { susceptible } \\
\text { strain } \\
\text { Additive in } \\
\text { resistant strain }\end{array}$ & Additive & Synergistic & $\begin{array}{l}\text { Synergistic in } \\
\text { lower doses } \\
\text { Antagonistic in } \\
\text { higher doses }\end{array}$ & $\begin{array}{l}\text { Additive in } \\
\text { susceptible } \\
\text { strain } \\
\text { Synergistic in } \\
\text { resistant strain }\end{array}$ & $\begin{array}{l}\text { Antagonistic in } \\
\text { susceptible } \\
\text { strain } \\
\text { Synergistic in } \\
\text { resistant strain }\end{array}$ \\
\hline $\begin{array}{c}\text { KAN } \\
\text { (MIC range } \\
0,164-0,657 \\
\text { mg/ml) }\end{array}$ & $\begin{array}{c}\text { Additive in } \\
\text { susceptible } \\
\text { strain } \\
\text { Antagonistic in } \\
\text { resistant strain }\end{array}$ & Synergistic & Additive & Additive & $\begin{array}{l}\text { Synergistic in } \\
\text { susceptible } \\
\text { strain } \\
\text { Antagonistic in } \\
\text { resistant strain }\end{array}$ & Antagonistic \\
\hline $\begin{array}{c}\text { PIP } \\
\text { (MIC range } \\
0,012-0,051 \\
\mathrm{mg} / \mathrm{ml})\end{array}$ & Additive & $\begin{array}{l}\text { Synergistic in } \\
\text { lower doses } \\
\text { Antagonistic in } \\
\text { higher doses }\end{array}$ & Additive & Additive & Synergistic & Synergistic \\
\hline $\begin{array}{c}\text { AMP } \\
\text { (MIC range } \\
\mathbf{1 , 3 5}-\mathbf{5 , 4} \\
\mathrm{mg} / \mathrm{ml})\end{array}$ & $\begin{array}{c}\text { Additive in } \\
\text { susceptible } \\
\text { strain } \\
\text { Antagonistic in } \\
\text { resistant strain }\end{array}$ & $\begin{array}{l}\text { Additive in } \\
\text { susceptible } \\
\text { strain } \\
\text { Synergistic in } \\
\text { resistant strain }\end{array}$ & $\begin{array}{l}\text { Synergistic in } \\
\text { susceptible } \\
\quad \text { strain } \\
\text { Antagonistic in } \\
\text { resistant strain }\end{array}$ & Synergistic & Additive & $\begin{array}{l}\text { Antagonistic in } \\
\text { susceptible } \\
\text { strain } \\
\text { Additive in } \\
\text { resistant strain }\end{array}$ \\
\hline $\begin{array}{c}\text { CHL (MIC } \\
\text { range } 0,055 \text { - } \\
0,22 \mathrm{mg} / \mathrm{ml})\end{array}$ & Antagonistic & $\begin{array}{l}\text { Antagonistic in } \\
\text { susceptible } \\
\text { strain } \\
\text { Synergistic in } \\
\text { resistant strain }\end{array}$ & Antagonistic & Synergistic & $\begin{array}{l}\text { Antagonistic in } \\
\text { susceptible } \\
\text { strain } \\
\text { Additive in } \\
\text { resistant strain }\end{array}$ & Additive \\
\hline
\end{tabular}


In addition, CHL-AMK and CHL-KAN combination found as antagonistic on both clinical strains, although drugs target different subunits of ribosome in their mechanism of action. In a previous study conducted with E. coli strain similar results were obtained ${ }^{[10,13]}$. In addition, KAN-AMK and AMK-AMP combination found as slightly antagonistic on resistant strain whereas additive on susceptible strain.

AMK-PIP and KAN-PIP combination found as additive on both strains. KAN-AMK and AMK-AMP found as additive on susceptible strain while antagonistic interaction was observed on resistant strain, which may be due to additional aminoglycoside and beta resistance genes presented in MDR strain (Table 3). Therefore, drug interaction experiments suggest that antibiotic combination therapy is a complex process and strains may respond differently to drug combination regimes. Thus, each strain should be screened for antibiotic interactions before combination therapy is given.

Yeh et al. studied pairwise interactions of 21 antibiotics on a susceptible E.coli strain and similar interaction patterns were observed. PIP-AMK interaction was found synergistic while CHL-AMK was found antagonistic, also CIP-PIP and AMK-PIP demonstrated additive interaction in our study.

AMK-AMP demonstrated additive interaction in a previous study, same drug combination was found additive and antagonistic in susceptible and resistant strain respectively in our study (YEH \& al [14]). This difference may be due to strA and strB aminoglycoside resistance genes, which only encountered in resistant strain.

According to a recent study conducted in Egypt different responses were noted with different MDR strains with same antibiotic combinations. AMK-AMP/sulbactam and AMK-CIP interaction found as either antagonistic or indifferent to $K$. pneumoniae strains, suggesting responses may differ from strain to strain that has different accessory genes (ABDELKADER \& al [15]).

Hirsch et al. assessed six antibiotic activities over two clinical carbapenemase producing $K$. pneumoniae strain in pairwise combinations with time-kill assay. Doripenem and amikacin combination demonstrated the most enhanced killing activity. Moreover, levofloxacin and amikacin combination was found as the most antagonistic drug combination on the strains. According to our study, ciprofloxacin and amikacin interaction evaluated as synergistic. Thus, it would be a bias to expect same responses after performing the same experiment with different antimicrobial agents belonging to same antibiotic group, in this case quinolones, suggesting all agents should be evaluated individually (HIRSCH \& al [16]).

Afunwa et al investigated pairwise combinations of five antibiotics with gentamicin over ESBL positive Enterobacteriaceae and Pseudomonas strains acquired from both community and hospital are noted as largely synergistic. Interestingly, different responses were obtained within the community and hospital isolates.
In some cases community isolates were found as more susceptible to synergistic antibiotic combinations than that of hospital isolates whereas the reverse trend might appear true for some combinations (AFUNWA \& al [17]). Responses may differ even though conducting the same experiment using same antimicrobial agents on different bacterial strains belonging to same family. In addition, drug doses used in vivo may differ when they are used in in vitro. Therapeutic and toxic doses of drugs can be found in previous studies (CHEN \& al [18]).

\section{Conclusion}

Emerging antimicrobial resistance in $K$. pneumoniae strains is an important problem worldwide. Lack of investments in new antibiotic developments of drug industry further complicates therapy of the serious infections. Antibiotic combination therapy is a rational approach however potential antagonistic effects of the drugs also the fact that different strains of same species may respond to therapy in different efficacy should not be ignored. This study shows preliminary but strong evidences that synergistic drug combinations would be a good strategy for fighting against the drug resistance. Although the study is limited for sample size, the importance of screening drug interactions is evidenced. In addition, more number of drug combinations should be screened for finding more potent fighting tools.

\section{References}

1. L. DIANCOURT, V. PASSET, J. VERHOEF, P.A.D. GRIMONT, S. BRISSE. Multilocus Sequence Typing of Klebsiella pneumoniae Nosocomial Isolates. J Clin Microbiol. August 2005; 43(8):4178-82.

2. C. PEÑA, M. PUJOL M, C. ARDANUY, A. RICART, R. PALLARES, J. LIÑARES, vd. Epidemiology and Successful Control of a Large Outbreak Due to Klebsiella pneumoniae Producing ExtendedSpectrum $\beta$-Lactamases. Antimicrob Agents Chemother. January 1998; 42(1):53-8.

3. M.E. FALAGAS, P.I. RAFAILIDIS, D. KOFTERIDIS, S. VIRTZILI, F.C. CHELVATZOGLOU, V. PAPAIOANNOU, vd. Risk factors of carbapenemresistant Klebsiella pneumoniae infections: a matched case control study. J Antimicrob Chemother. November 2007; 60(5):1124-30.

4. K.K KUMARASAMY, M.A.TOLEMAN, T.R. WALSH, J. BAGARIA, F. BUTT, R. BALAKRISHNAN, vd. Emergence of a new antibiotic resistance mechanism in India, Pakistan, and the UK: a molecular, biological, and epidemiological study. Lancet Infect Dis. September 2010; 10(9):597-602.

5. D.L PATERSON, K.M. HUJER, A.M. HUJER, B. YEISER, M.D. BONOMO, L.B. RICE, vd. ExtendedSpectrum $\beta$-Lactamases in Klebsiella pneumoniae Bloodstream Isolates from Seven Countries: Dominance and Widespread Prevalence of SHV- and CTX-M- 
Type $\beta$-Lactamases. Antimicrob Agents Chemother. November 2003; 47(11):3554-60.

6. M. SHANTHI, U. SEKAR. Extended spectrum beta lactamase producing Escherichia coli and Klebsiella pneumoniae: risk factors for infection and impact of resistance on outcomes. J Assoc Physicians India. December 2010; 58 Suppl:41-4.

7. National Nosocomial Infections Surveillance System. National Nosocomial Infections Surveillance (NNIS) System Report, data summary from January 1992 through June 2004, issued October 2004. Am J Infect Control. December 2004; 32(8):470-85.

8. P. NORDMANN, G. CUZON, T. NAAS. The real threat of Klebsiella pneumoniae carbapenemaseproducing bacteria. Lancet Infect Dis. April 2009; 9(4):228-36.

9. N. ABDUL RAHIM, S.E CHEAH, M.D. JOHNSON, H. YU, H.E. SIDJABAT, J. BOYCE, vd. Synergistic killing of NDM-producing MDR Klebsiella pneumoniae by two 'old' antibiotics-polymyxin B and chloramphenicol. J Antimicrob Chemother. September 2015; 70(9):2589-97.

10. S. CHANDRASEKARAN, M. COKOL-CAKMAK, N. SAHIN, K. YILANCIOGLU, H. KAZAN, J.J COLLINS, vd. Chemogenomics and orthology-based design of antibiotic combination therapies. Mol Syst Biol. May 2016; 12(5):n/a-n/a.

11. J.J. RAHAL. Novel antibiotic combinations against infections with almost completely resistant Pseudomonas aeruginosa and Acinetobacter species. Clin Infect Dis Off Publ Infect Dis Soc Am. September 2006; 43 Suppl 2:S95-99.

12. B. YADAV, K. WENNERBERG, T. AITTOKALLIO, J. TANG. Searching for Drug Synergy in Complex Dose-Response Landscapes Using an Interaction Potency Model. Comput Struct Biotechnol J. September $2015 ; 13: 504-13$.

13. K. YILANCIOGLU, O. UNLU. Multidrug resistance stimulated antagonistic antibiotic interactions. Rom J Leg Med. December 2017; 25(4):331-6.
14. P. YEH, A.I. TSCHUMI, R. KISHONY. Functional classification of drugs by properties of their pairwise interactions. Nat Genet. April 2006; 38(4):489-94.

15. M.M. ABDELKADER, K.M. ABOSHANAB, M.A. EL-ASHRY, M.M. ABOULWAFA. Prevalence of MDR pathogens of bacterial meningitis in Egypt and new synergistic antibiotic combinations. PLOS ONE. 2017; 12(2):e0171349.

16. E.B. HIRSCH, B. GUO, K.T. CHANG, H. CAO, K.R. LEDESMA, M. SINGH, vd. Assessment of antimicrobial combinations for Klebsiella pneumoniae carbapenemase-producing K. pneumoniae. J Infect Dis. March 2013; 207(5):786-93.

17. R.A. AFUNWA, D.C. ODIMEGWU, R.I. IROHA, C.O. ESIMONE. Antibiotic combinatorial approach utilized against extended spectrum beta-lactamase (ESBL) bacteria isolates from Enugu, South Eastern Nigeria. J Health Sci. April 2014; 4(1):19-25.

18. S. CHEN, S. ZHAO, D.G. WHITE, C.M. SCHROEDER, R. LU, H. YANG, vd. Characterization of multiple-antimicrobial-resistant salmonella serovars isolated from retail meats. Appl Environ Microbiol. January 2004; 70(1):1-7.

19. V. CATTOIR, L. POIREL, V. ROTIMI, C.J. SOUSSY, P. NORDMANN. Multiplex PCR for detection of plasmid-mediated quinolone resistance qnr genes in ESBL-producing enterobacterial isolates. J Antimicrob Chemother. August 2007; 60(2):394-7.

20. J. HUR, Y.Y. CHOI, J.H. PARK, B.W. JEON, H.S. LEE, A.R. KIM, vd. Antimicrobial resistance, virulence-associated genes, and pulsed-field gel electrophoresis profiles of Salmonella enterica subsp. enterica serovar Typhimurium isolated from piglets with diarrhea in Korea. Can J Vet Res. January 2011; 75(1):49-56.

21. R.S. LEVINGS, S.R. PARTRIDGE, D. LIGHTFOOT, R.M. HALL, S.P. DJORDJEVIC. New IntegronAssociated Gene Cassette Encoding a 3-N-Aminoglycoside acetyltransferase. Antimicrob Agents Chemother. March 2005; 49(3):1238-41. 